\title{
The role of microRNAs in acute myeloid leukemia
}

\author{
R Katherine Hyde and P Paul Liu*
}

\author{
Address: Genetics and Molecular Biology Branch, NHGRI/NIH, 49 Convent Drive, Bethesda, MD 20892, USA \\ *Corresponding author: P Paul Liu (pliu@mail.nih.gov) \\ FI000 Biology Reports 2010, 2:8I (doi:10.34I0/B2-8I) \\ This is an open-access article distributed under the terms of the Creative Commons Attribution-Non Commercial License \\ (http://creativecommons.org/licenses/by-nc/3.0/legalcode), which permits unrestricted use, distribution, and reproduction in any medium, \\ provided the original work is properly cited. You may not use this work for commercial purposes. \\ The electronic version of this article is the complete one and can be found at: http://f1000.com/reports/b/2/8I
}

\begin{abstract}
MicroRNAs (miRs) are short (18-22 nucleotides) non-coding RNAs that are important in regulating gene expression. MiR expression is deregulated in many types of cancers, including leukemias. In acute myeloid leukemia (AML), the expression of specific miRs has been linked with both prognostically and cytogenetically defined subgroups. Recent studies have shown that deregulation of miR expression is not simply a consequence of AML but a potential contributer to leukemogenesis. This commentary will focus on select findings that describe the different mechanistic roles for miRs in the development of leukemia.
\end{abstract}

\section{Introduction and context}

Acute myeloid leukemia (AML) is a heterogeneous disease that is often classified by the presence of specific, recurrent chromosomal alterations that generate unique oncogenic fusion genes. These alterations are associated with the expansion of cells that have arrested at different stages of differentiation, and have distinct prognoses and gene expression profiles (reviewed in $[1,2]$ ). Recently, it has been shown that different subtypes of AML are also associated with distinct microRNA (miR) profiles.

MiRs are small non-coding RNAs that are thought to regulate gene expression by base pairing with the $3^{\prime}$ untranslated region of a target gene mRNA, leading to degradation and/or translational repression. Each individual miR is thought to have multiple target genes and it has been proposed that miRs may represent a mechanism for cells to quickly change the expression of a large number of genes, as required during processes such as differentiation. Consistent with this hypothesis, it has been shown that the profile of expressed miRs changes significantly during hematopoietic differentiation (reviewed in $[3,4]$ ).

Different subtypes of AML have also been associated with different miR expression profiles. Multiple studies have shown that unsupervised clustering using miR expression strongly correlates with known morphological and cytogenic subgroups [5-8]. In addition, it has been shown that distinct miR expression signatures correlate with AML survival rates [12]. There are extensive reviews concerning miR expression and AML subgroups and prognoses, (see e.g., $[13,14]$ ).

The relationship between the expression of a specific miR (or group of miRs) and AML subtype has important implications for prognosis and treatment of AML $[11,12]$. However, as it is known that miR expression changes with normal hematopoietic differentiation $[3,4]$, it is possible that the differential expression of many miRs in AML could be due to the stage at which differentiation arrest of the leukemic blasts occured and may not have a causal role in the leukemic process. However, some recent studies have described a mechanistic role for individual miRs in the development of AML and will be the focus of this review.

\section{Major recent advances}

One of the first studies to show a role for a specific $\mathrm{miR}$ in AML was Li et al. [8]. They found that increased expression of miR-126/126* was not only associated with the AML subgroups carrying the related chromosomal alterations $\mathrm{t}(8: 21)$ and $\operatorname{inv}(16)$, it also inhibited apoptosis and increased AML cell viability. They also 
showed that this effect was likely mediated through decreased expression of the miR-126/126* target, which encodes the tumor suppressor PLK2 (Polo-like kinase 2). Interestingly, Li et al. [8] showed that the increased expression of miR-126/126* was likely mediated by promoter hypomethylation.

Recent evidence suggests that repression of miR-29b may also play a causative role in the AML subgroups defined by $\mathrm{t}(8: 21)$ and inv(16). Decreased expression of miR-29b was shown to indirectly cause increased expression of the tyrosine kinase KIT [15] and contribute to leukemogenesis. This finding is of particular interest in regard to $\mathrm{t}(8: 21)$ and $\operatorname{inv}(16)$ AMLs because gainof-function mutations in KIT are known to be associated with decreased survival in patients in this AML cytogenetic subgroup [16].

Causative roles for miRs have also been described in AMLs with fusion genes involving the mixed-lineage leukemia $(M L L)$ gene. Popovic et al. [17] showed that the MLL-AF9 fusion gene caused overexpression of miR$196 \mathrm{~b}$ and that expression of this miR was required for MLL-AF9-induced immortilization.

A similar role for the miR-17-92 cluster in leukemias expressing MLL fusion genes has also been identified. Like miR-196b, individual miRs in the miR17-92 cluster were shown to be overexpressed in leukemias with $M L L$ rearrangements, which increased proliferation and decreased apoptosis [18,19]. Interestingly, Mi et al. [18] showed that MLL fusion proteins were capable of binding the promoter region of the miR17-92 cluster and activating the expression of the individual miRs. This indicates that these miRs not only play a functional role in MLL-rearranged AML, but are also direct targets of the fusion genes.

A potential role for miR-125b-2, located on chromosome 21 , has recently been connected to trisomy $21 /$ Down syndrome-related acute megakaryoblastic leukemia (DS-AMKL) [20]. Overexpression of miR-125b-2 was shown to increase proliferation and self-renewal, and these effects were accentuated in the presence of the GATA1 mutation that results in the expression of GATA1s (the short isoform), which is present in nearly all cases of DS-AMKL [21,22]. In addition, Klusmann et al. [20] identified two potential downstream targets of miR-125b-2, DICER1 and ST18, both of which are genes previously shown to be downregulated in cancer.

\section{Future directions}

The examples discussed in this review indicate that deregulated expression of miRs can be an important step in leukemogenesis and that the expression of miRs can be affected by a number of different mechanisms. Continued investigation into the role of miRs and their target genes promises to yield new insights into the mechanisms of leukemogenesis. Most importantly, miRs may represent an important target for the development of new therapeutics for the treatment of AML. As an individual miR is likely to affect the expression of several different genes, therapies directed at miRs could potentially target multiple leukemogenic processes.

\section{Abbreviations}

AML, acute myeloid leukemia; DS-AMKL, Down syndrome-related acute megakaryoblastic leukemia; miR, microRNA; MLL, mixed-lineage leukemia.

\section{Competing interests}

The authors declare that they have no competing interests.

\section{Acknowledgements}

This work was supported by the Intramural Research Program of National Human Genome Research Institute, National Institutes of Health.

\section{References}

I. Vardiman JW, Thiele J, Arber DA, Brunning RD, Borowitz MJ, Porwit A, Harris NL, Le Beau MM, Hellström-Lindberg E, Tefferi A, Bloomfield CD: The 2008 revision of the World Health Organization (WHO) classification of myeloid neoplasms and acute leukemia: rationale and important changes. Blood 2009, I |4:937-5I.

2. Mrozek K, Radmacher MD, Bloomfield CD, Marcucci G: Molecular signatures in acute myeloid leukemia. Curr Opin Hematol 2009, 1 6:64-9.

3. Navarro F, Lieberman J: Small RNAs guide hematopoietic cell differentiation and function. J Immuno 2010, I 84:5939-47.

4. Vasilatou D, Papageorgiou S, Pappa V, Papageorgiou E, Dervenoulas J: The role of microRNAs in normal and malignant hematopoiesis. Eur J Haematol 2010, 84: I-16.

5. Debernardi S, Skoulakis S, Molloy G, Chaplin T, Dixon-Mclver A, Young BD: MicroRNA miR-I8Ia correlates with morphological sub-class of acute myeloid leukaemia and the expression of its target genes in global genome-wide analysis. Leukemia 2007, 21:912-6.

6. Dixon-Mclver A, East P, Mein CA, Cazier JB, Molloy G, Chaplin T, Andrew Lister T, Young BD, Debernardi S: Distinctive patterns of microRNA expression associated with karyotype in acute myeloid leukaemia. PLoS One 2008, 3:e2I4I.

7. Jongen-Lavrencic M, Sun SM, Dijkstra MK, Valk PJ, Lowenberg B: MicroRNA expression profiling in relation to the genetic heterogeneity of acute myeloid leukemia. Blood 2008, I I I:5078-85.

8. Li Z, Lu J, Sun M, Mi S, Zhang H, Luo RT, Chen P, Wang Y, Yan M, Qian Z, Neilly MB, Jin J, Zhang $Y$, Bohlander SK, Zhang DE, Larson RA, Le Beau MM, Thirman MJ, Golub TR, Rowley JD, Chen J: Distinct microRNA expression profiles in acute myeloid leukemia with common translocations. Proc Natl Acad Sci U S A 2008, 105:I5535-40.

9. Marcucci G, Radmacher MD, Maharry K, Mrózek K, Ruppert AS, Paschka P, Vukosavljevic T, Whitman SP, Baldus CD, Langer C, Liu CG, Carroll AJ, Powell BL, Garzon R, Croce CM, Kolitz JE, 
Caligiuri MA, Larson RA, Bloomfield CD: MicroRNA expression in cytogenetically normal acute myeloid leukemia. N Engl J Med 2008, 358:1919-28.

FI000 Factor 8

Evaluated by Aldo Roccaro II Aug 2008

10. Garzon R, Volinia S, Liu CG, Fernandez-Cymering C, Palumbo T, Pichiorri F, Fabbri M, Coombes K, Alder H, Nakamura T, Flomenberg N, Marcucci G, Calin GA, Kornblau SM, Kantarjian H, Bloomfield $C D$, Andreeff $M$, Croce CM: MicroRNA signatures associated with cytogenetics and prognosis in acute myeloid leukemia. Blood 2008, II I:3 I83-9.

II. Blum W, Garzon R, Klisovic RB, Schwind S, Walker A, Geyer S, Liu S, Havelange V, Becker H, Schaaf L, Mickle J, Devine H, Kefauver C, Devine SM, Chan KK, Heerema NA, Bloomfield CD, Grever MR, Byrd JC, Villalona-Calero M, Croce CM, Marcucci G: Clinical response and miR-29b predictive significance in older AML patients treated with a 10-day schedule of decitabine. Proc Natl Acad Sci U S A 2010, 107:7473-8.

12. Whitman SP, Maharry K, Radmacher MD, Becker H, Mrózek K, Margeson D, Holland KB, Wu YZ, Schwind S, Metzeler KH, Wen J, Baer MR, Powell BL, Carter TH, Kolitz JE, Wetzler M, Moore JO, Stone RM, Carroll AJ, Larson RA, Caligiuri MA, Marcucci G, Bloomfield CD: FLT3 internal tandem duplication associates with adverse outcome and gene- and microRNA-expression signatures in patients 60 years of age or older with primary cytogenetically normal acute myeloid leukemia: a Cancer and Leukemia Group B study. Blood 2010, [Epub ahead of print].

13. Marcucci G, Radmacher MD, Mrózek K, Bloomfield CD: MicroRNA expression in acute myeloid leukemia. Curr Hematol Malig Rep 2009, 4:83-8.

14. Seca H, Almeida GM, Guimaraes JE, Vasconcelos MH: miR signatures and the role of $\mathrm{miRs}$ in acute myeloid leukaemia. Eur J Cancer 2010, 46:1520-7.

15. Liu S, Wu LC, Pang J, Santhanam R, Schwind S, Wu YZ, Hickey CJ, Yu J, Becker H, Maharry K, Radmacher MD, Li C, Whitman SP, Mishra A, Stauffer N, Eiring AM, Briesewitz R, Baiocchi RA, Chan KK, Paschka P, Caligiuri MA, Byrd JC, Croce CM, Bloomfield CD, Perrotti D, Garzon R, Marcucci G: SpI/NFkappaB/HDAC/miR- 29b regulatory network in KIT-driven myeloid leukemia. Cancer Cell 2010, 17:333-47.

16. Paschka P, Marcucci G, Ruppert AS, Mrózek K, Chen H, Kittles RA, Vukosavljevic T, Perrotti D, Vardiman JW, Carroll AJ, Kolitz JE, Larson RA, Bloomfield CD; Cancer and Leukemia Group B: Adverse prognostic significance of KIT mutations in adult acute myeloid leukemia with inv(16) and t(8;2I): a Cancer and Leukemia Group B Study. J Clin Oncol 2006, 24:3904-II.

17. Popovic R, Riesbeck LE, Velu CS, Chaubey A, Zhang J, Achille NJ, Erfurth FE, Eaton K, Lu J, Grimes HL, Chen J, Rowley JD, ZeleznikLe NJ: Regulation of mir-196b by MLL and its overexpression by MLL fusions contributes to immortalization. Blood 2009, | | 3:33|4-22.

18. Mi S, Li Z, Chen P, He C, Cao D, Elkahloun A, Lu J, Pelloso LA, Wunderlich M, Huang H, Luo RT, Sun M, He M, Neilly MB, ZeleznikLe NJ, Thirman MJ, Mulloy JC, Liu PP, Rowley JD, Chen J: Aberrant overexpression and function of the miR-17-92 cluster in MLLrearranged acute leukemia. Proc Natl Acad Sci U S A 2010, 107:3710-5.

19. Wong P, Iwasaki M, Somervaille TC, Ficara F, Carico C, Arnold C, Chen CZ, Cleary ML: The miR-17-92 microRNA polycistron regulates MLL leukemia stem cell potential by modulating p2I expression. Cancer Res 2010, 70:3833-42.

20. Klusmann JH, Li Z, Bohmer K, Maroz A, Koch ML, Emmrich S, Godinho F], Orkin SH, Reinhardt D: miR-I25b-2 is a potential oncomiR on human chromosome $2 \mathrm{I}$ in megakaryoblastic leukemia. Genes Dev 2010, 24:478-90.

21. Wechsler J, Greene M, McDevitt MA, Anastasi J, Karp JE, Le Beau MM, Crispino JD: Acquired mutations in GATAI in the megakaryoblastic leukemia of Down syndrome. Nat Genet 2002, 32:148-52.

FI000 Factor 6

Evaluated by Leonard Zon 01 Oct 2002

22. Mundschau G, Gurbuxani S, Gamis AS, Greene ME, Arceci RJ, Crispino JD: Mutagenesis of GATAI is an initiating event in Down syndrome leukemogenesis. Blood 2003, 101:4298-300. 